\title{
Analysis of the application of combined solar-assisted accumulation ground source heat pump system for heat supply of the building
}

\author{
Boris Basok ${ }^{1}$, Aleksandr Nedbailo ${ }^{2}$, Olena Tutova ${ }^{3}$, Myroslav Tkachenko ${ }^{4}$, Ihor Bozhko ${ }^{5}$ \\ Institute of Engineering Thermophysics National Academy of Science of Ukraine \\ Department of Thermophysical Basics of Energy-Saving Technologies \\ str. Bulakhovskogo, 2, Bldg. 2, of. 201, Kyiv, Ukraine, 03164 \\ 1basok@ittf.kiev.ua, orcid.org/0000-0002-8935-4248 \\ 2 nan_sashulya@ukr.net, orcid.org/0000-0003-1416-9651 \\ ${ }^{3}$ riasnovaelen@gmail.com, orcid.org/0000-0001-6846-0327 \\ 4tkamyr@gmail.com, orcid.org/0000-0001-8345-1613 \\ 5bozhkoik@gmail.com, orcid.org/0000-0001-7458-0835
}

DOI: $10.32347 / 2310-0516.2019 .12 .30-41$

Annotation. The scheme of technical solutions and estimated calculations of the main parameters of the heat supply system of the administrative building using solar energy and ground collector heat energy are presented. The scheme consists of three circuits (heating, solar collector and heat pump), passing through a tank-accumulator, which allows them to be hydraulically solved with the implementation of heat exchange, as well as the contour of the vertical ground collector. In the cold period of the year, there is an accumulation of heat in the tank-accumulator due to the use of the heat of insolation and regenerative heat of ground by a heat pump.

By regulating the flow of heat-carrier in the circuits and switching them, the required temperature in the tank-accumulator and for the heating circuit is maintained. Depending on the heating load, options for joint or single use of heat sources are possible. The following technological variants of the system operation are considered: circulation of coolant through a solar collector and a ground heat exchanger, circulation of a coolant through a solar collector and a heat pump, circulation of a coolant through a soil heat exchanger and a heat pump, circulation of a coolant through a solar collector to the consumer.

Share of the building heat loss which can be covered by a solar collector for the cold period of the year is estimated. The estimated technical and economic analysis of financial expenses with an application of a combined solar-assisted accumulation ground source heat pump system
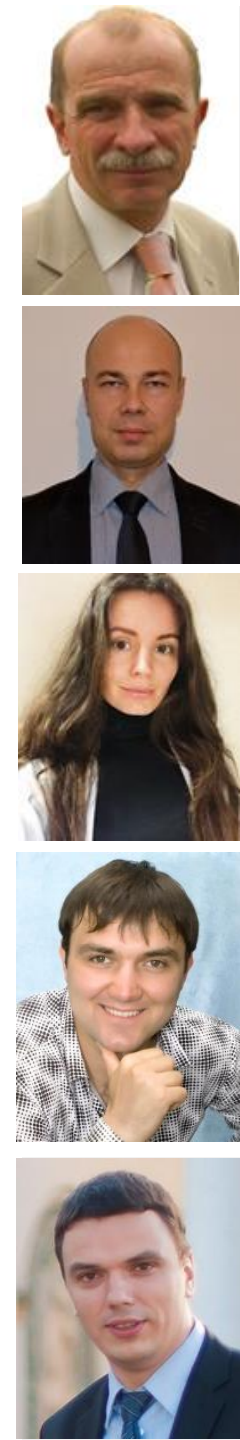

Nedbailo Aleksandr

$\mathrm{PhD}$, Senior scientist

Basok Boris

Doctor of Science, Professor

Tutova Olena

Graduate, Scientist

Tkachenko Myroslav

Bozhko Ihor 
for the heat supply of the building is presented. For the preliminary estimation of the main financial indicators, two variants of the building heating system are considered: taking into account the hot water supply in the first case and without it.

The comparison of energy efficiency of the solar-assisted accumulation ground source heat pump system with the traditional heating system at various tariffs for natural gas has been carried out.

Keywords: ground heat exchanger; heat pump; solar collector; heat supply.

\section{INTRODUCTION}

Due to the energy crisis, it is becoming necessary to increasingly using of unconventional energy resources, and the most applicable are solar energy and heat pumps. In most countries of the world insolation which falls on the surface of buildings, greatly exceeds the amount of energy consumed by the buildings per year. Solar collectors in combination with heat pumps of various types and designs allow to organize the heat supply of residential, industrial and administrative buildings, as well as provide them hot water. The relevance of using such systems today is indisputable. At the Institute of Technical Thermophysics of the National Academy of Sciences of Ukraine, has been established and is being developed a Center for Heat Pump Technologies in which are being carried out the studies of energy and economic efficiency of using solar assisted ground source heat pump heating systems. The authors conducted an appraisal technical and economic analysis of the financial costs of using a combined solar assisted ground source heat pump system for heating the building and comparing its energy efficiency with the traditional heat supply system during different tariffs for natural gas.

\section{REFERENCE ANALYSIS AND PROBLEM STATEMENT}

As is known, the potential of alternative energy, based on solar insolation, is extremely high for Ukraine [1,2]. The International Energy Agency has established that using only $1.5 \%$ of the amount of solar energy could provide all of today's global energy needs, and the implementation of $5.0 \%$ it's would completely cover the needs for the future $[3,4]$. One of the most effective and widespread methods of energy production in the world is the conversion of solar radiation into the heat energy.

The prospect of using solar radiation is determined by its availability and low payback period of the projects being implemented compared to traditional methods of energy production. The results of processing statistical meteorological data are presented in Fig. 1 in the form of the potential distribution of the solar energy over the territory of Ukraine $[3,4,5,6]$. These data indicate its widespread availability and sufficient quantities to solve energy problems.

Usually, in solar heating systems are applied solar collectors which are designed to heat the heating carrier during insolation. At the same time, the temperature potential of solar collectors fluctuates within $50-60{ }^{\circ} \mathrm{C}$. Heat carrier with such parameters is rationally apply for the needs of municipal heating and power engineering - low-temperature heating systems (underfloor heating, walls) and hot water supply. The results of experimental studies conducted in various countries of the world $[7,8,9,10,11]$ allow us to conclude that such systems are promising, especially for building heating. Volume of implementation of combined heating systems with solar collectors and heat pump in the CIS countries is quite small and is constrained due to the lack of a proven methodology for their calculation and design. In this regard, the development of solar systems with solar collectors and ground source heat pump for heating and hot water supply is an important task of energy saving.

\section{GOALS AND OBJECTIVES OF THE STUDY}

The aim of the study is a comprehensive investigation of the operation options features and the effectiveness of a ground source heat pump in combination with a solar collector and the development of scientific and practical bases for their application, taking into account 
Ukrainian natural and climatic conditions, as a practical basis for creating regional and sectoral energy and resource saving programs, and also adaptation and development of joint application of energy technologies using various renewable non-traditional energy sources.

To achieve this goal the following tasks were solved:

1. Study of two hydraulic schemes of an experimental heat supply system

2. Calculation of the possibility of covering the heat loss of the building by using solar collectors

3. The economic feasibility of combined ground source heat pump system.

The overview of international experience is described in $[12,13]$.

\section{RESEARCH METHODS}

The Center research team has designed the principal hydraulic circuits and conducted of laboratory equipment selection for space heating system of $18 \mathrm{~m}^{2}$ using a flat solar collector Roth Heliostar 252 with an aperture area of $2.3 \mathrm{~m}^{2}$. Its efficiency is, respectively, optical $95 \%$, and thermal $65 \%$, which is achieved by using a highly selective coating and selective single glazing. In this case, the estimated annual contribution of the collector according to the manufacturer parameters can be at least $525 \mathrm{~kW} \cdot \mathrm{h} / \mathrm{m}^{2}$ with a recommended installation angle of $50^{\circ}$.

Fig. 2 shows a combined hydraulic scheme of an experimental heating system. A feature of the scheme is the absence of a storage tank. Designations are given below.

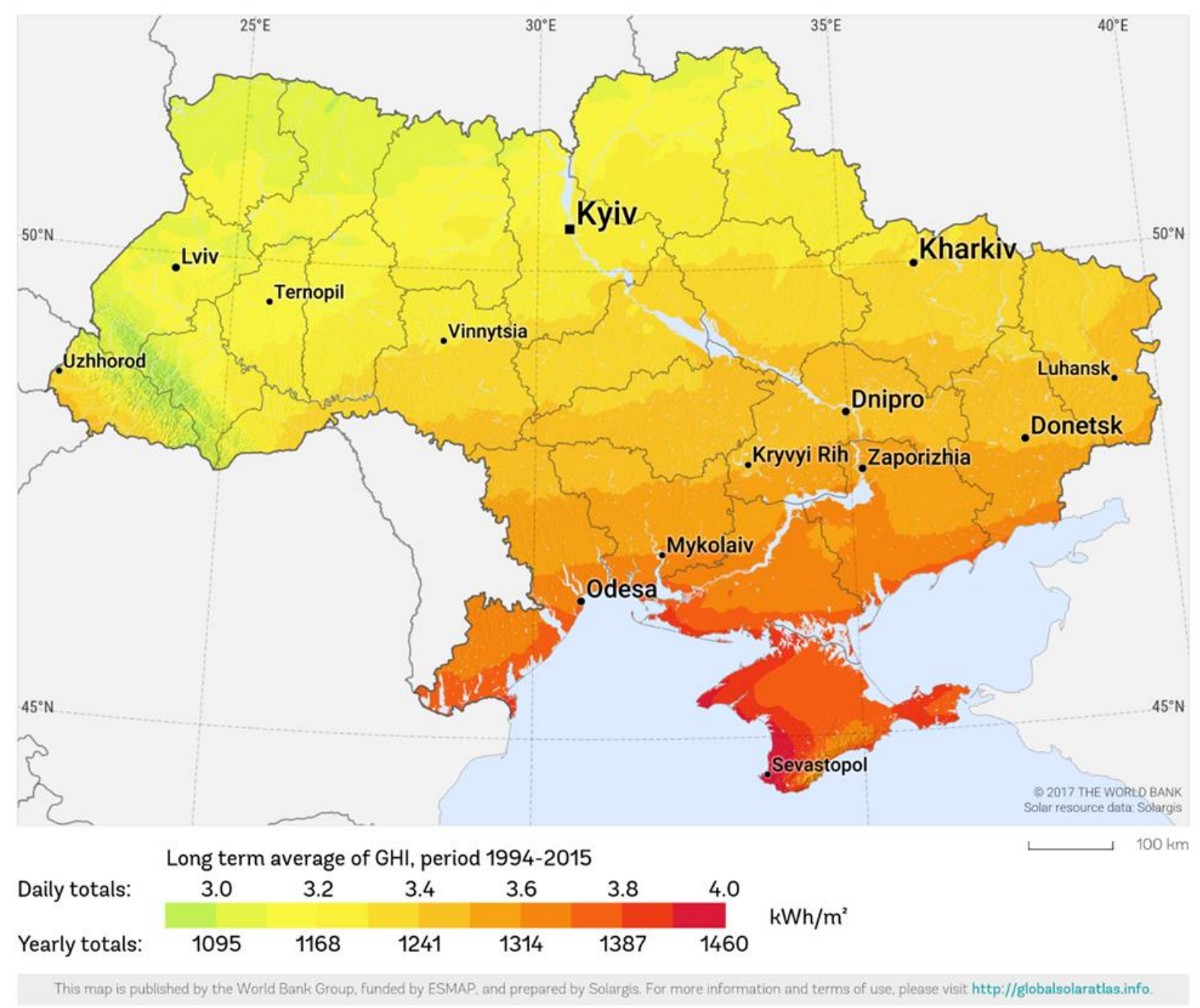

Fig. 1. The potential of solar insulation on the territory of Ukraine. 


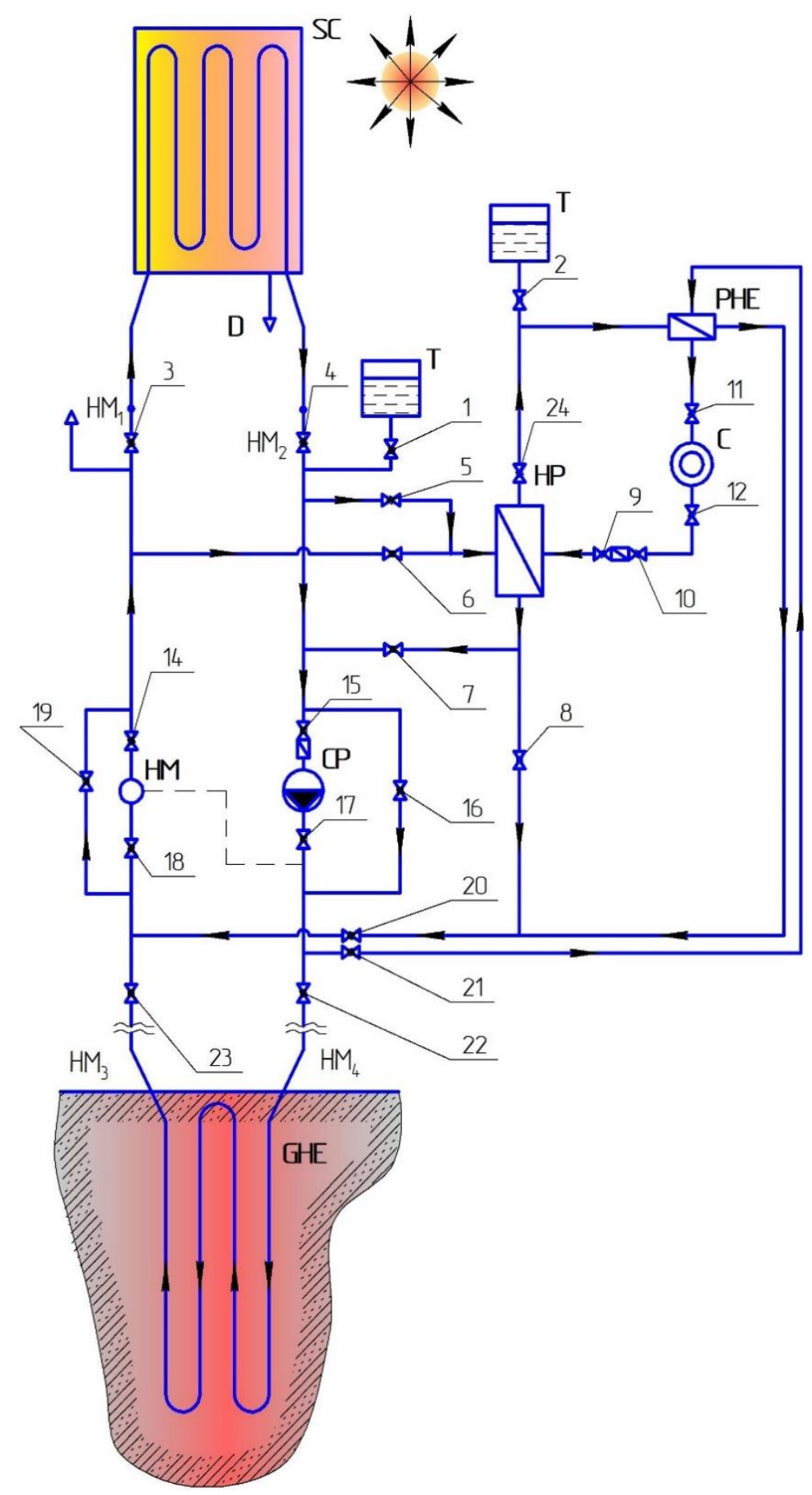

Fig. 2. Hydraulic circuit of an experimental combined heating system without using a storage tank.

$\mathrm{SC}$ - solar collector, D - drainage, $\mathrm{T}$ membrane expansion tank, C - consumer, HP heat pump, CP - circulation pump, GHE ground heat exchanger, PHE - plate heat exchanger, $\mathrm{HM}$ - heat meter, $\mathrm{HM}_{1} \geq \mathrm{HM}_{2}$ pump switched off.

The following technological options for system operation are possible:
1. The circulation of heat carrier through the solar collector SC and ground heat exchange GHE. At the same time, the taps are open: $1,3,4,15,17,22,23,18,14$; taps closed: $5,6,7,16,19,20,21$. centrifugal pump is working. There is a direct heat flow from the solar collector to the vertical ground source heat exchanger. This mode can be used 
to study the processes of heat distribution in the soil, as well as compensation of the thermal state in the warm season.

2. Circulation of the heat carrier through the SC and heat pump HP. In this mode, the taps are open: $1,3,4,5,8,20,18,14,24,11,19,10$, 12; the taps are closed: $6,7,13,21,22,23,17$, $16,15,19,13$. centrifugal pump is off. This occurs, the increasing of the heat carrier temperature potential in the heating system. This mode is intended for space heating in the cold season.

3. The circulation of heat carrier through the GHE and HP. At the same time, the taps are open: $22,23,18,14,6,7,16,1,24,12,11,10$, 9; the taps are closed: 19, 20, 21, 15, 17, 8, 5, 3, 4,13 . Centrifugal pump must be turned off. The extraction of both natural and renewable heat from the ground is occurring, followed by an increase in its temperature potential in the heat pump. Applying of this mode is appropriate when it is impossible for a solar collector to develop sufficient thermal power.

4. The circulation of heat carrier through the $\mathrm{SC}$ and consumer $\mathrm{C}$. The valves should be open: $1,2,3,4,15,17,21,11,12,13,20,18$, 14; closed taps: 22, 23, 16, 19, 9, 10, 7, 8, 24, 5, 6. At the same time, the centrifugal pump operate, provides heating directly to consumer. It is possible to use such operation mode of the system during transition periods of the heating season with a small heat load.

Circulation of the heat carrier (water) in the heating circuit is carried out in options 2, 3, 4 . The heat carrier in all circuits besides the heating circuits is a $28 \%$ aqueous ethylene glycol. To measure the amount of heat in each of the modes, the Apator LQM-III-K heat meter is designed with the possibility of computer processing and analysis of data SWEP E12T was selected as the plate heat exchanger.

The disadvantage of this scheme is the difficulty of coordinating the flow of the heat carrier in heat exchangers to achieve effective heat exchange, as well as the need to complicate the automatic control and management system of measuring equipment and valves.

In this regard, a variant of the heating system was developed using a heat-insulated three- circuit storage tank Roth BW 300 with a capacity of 300 liters. The area of its heat exchangers ground type, respectively, heating system contours is $1.0 \mathrm{~m}^{2}$ and solar collector is $1.5 \mathrm{~m}^{2}$. The hydraulic diagram of this solution is shown in Fig. 3

The scheme consists of three circuits (heating, solar collector and heat pump) passing through the storage tank, which allows them to hydraulically decouple from the implementation of heat exchange, as well as the contour of the vertical ground collector. In the cold period of the year, heat accumulates in the storage tank through using of insolation heat and renewable heat of the soil with the using the heat pump.

By regulating the flow of heat carrier in the circuits and switching them maintained the required temperature in the storage tank and the heating circuit. Depending on the heating load, joint or single use of heat sources are possible. In this case, the scheme allows, as in the first case, to investigate the dynamics of heat propagation in the soil massif, as well as to compensate for its thermal state during the warm period of the year. The measurement of the heat amount is provided by installing in all circuits of heat meters, implementing automatic registration meters with different frequency.

SC - solar collector, ST - storage tank, T membrane expansion tank, $\mathrm{C}$ - consumer, HP heat pump, CP - circulation pump, GHE ground heat exchanger, HM - heat meter, HM1 ... HM10 - temperature sensors, HM1 $\geq \mathrm{T} 2$ - the pump is off. In both variants of the system, when the heat carrier reaches the temperature value returning to the solar collector, the circulation pump should automatically be turned off. A heat pump with a power of $2 \mathrm{~kW}$ is sufficient for efficient system operation. All temperature sensors are proposed to be used with secondary devices, allowing real-time recording of parameters and their subsequent analysis. To compensate for the volume the fluid during temperature expansion in each circuit membrane tanks are provided. Vertical double ground U-shaped heat exchanger made of polypropylene pipes $32 \times 3 \mathrm{~mm}$, is located in a well with a depth of $25 \mathrm{~m}$ at the Institute territory. 


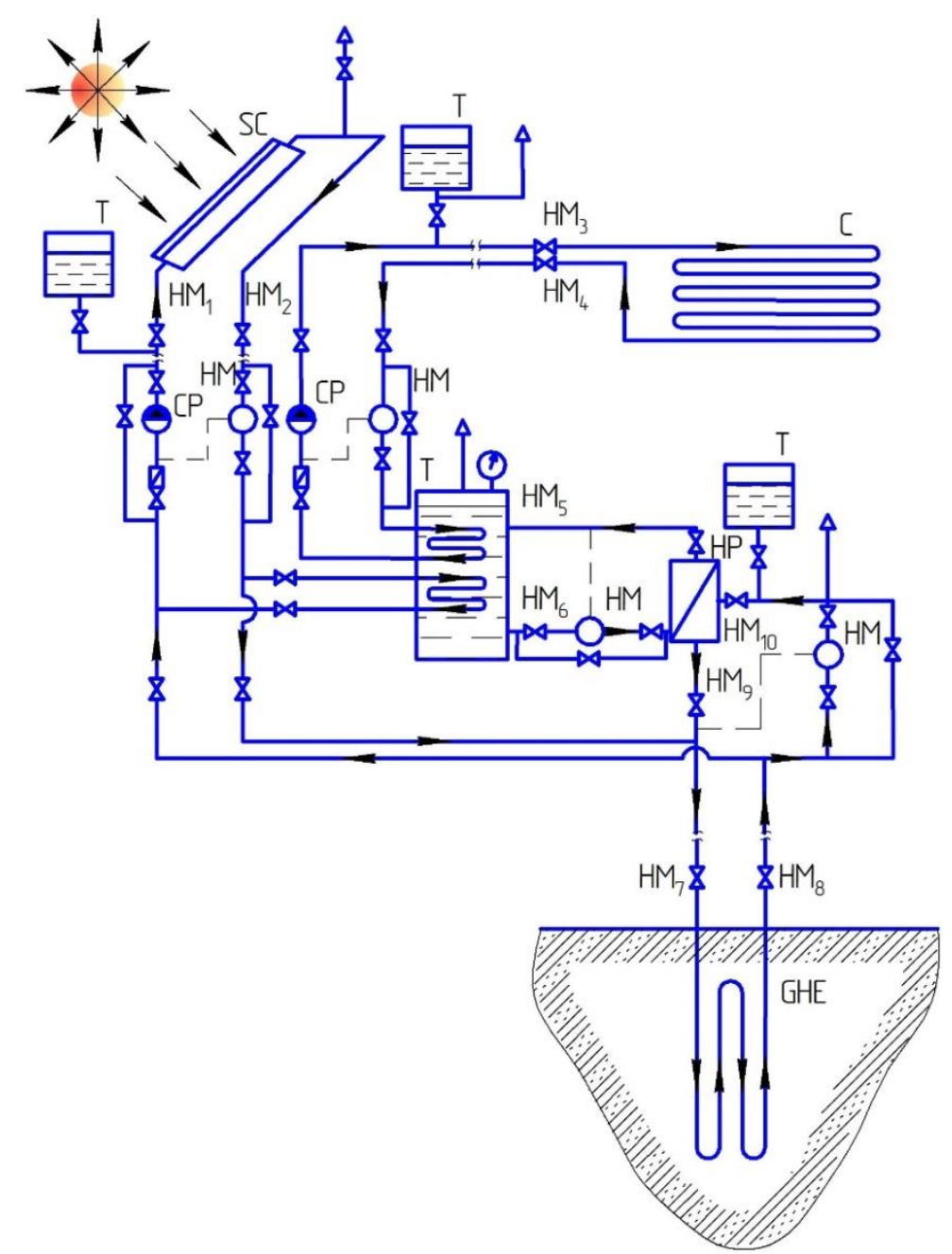

Fig. 3. Hydraulic circuit of an experimental combined heating system with using a storage tank.

\section{RESEARCH RESULTS}

The results of the preliminary estimated calculations of the main thermal indices, carried out according to the method $[14,15]$, are presented below. According to calculations [16], the heat losses of the laboratory building were $1328 \mathrm{~W}$. At the same time, the average monthly temperatures for the city of Kiev [17] were taken: January $=-4.3^{\circ} \mathrm{C}$, February $=-$ $3.3^{\circ} \mathrm{C}$, March $=1.3^{\circ} \mathrm{C}$, April $=8.9^{\circ} \mathrm{C}$, May $=15,1^{\circ} \mathrm{C}$, June $=18.3^{\circ} \mathrm{C}$, July $=19.5^{\circ} \mathrm{C}$, August $=18.9^{\circ} \mathrm{C}$, September $=13.8^{\circ} \mathrm{C}$, October $=7.9^{\circ} \mathrm{C}$, November $=1,8{ }^{\circ} \mathrm{C}$, December $=-2.0^{\circ} \mathrm{C}$. The obtained values of the average monthly heat input from the solar collector to the heating system were compared with data from [16]. Comparison histograms are shown in Fig. 4.

The comparison showed that the difference in the cold period of the year averages $21 \%$, while in the warm period it is about $15 \%$. Such a difference can be explained by the fact that in the method [16] the thermal efficiency and the angle of inclination to the horizon are calculated for each month separately, and in the method [14,15] are taken, respectively, constant. It should be noted that the average angle in the cold period of the year is 49.9 , in the warm period 21.6, and the average annual 35.0 [18]. 


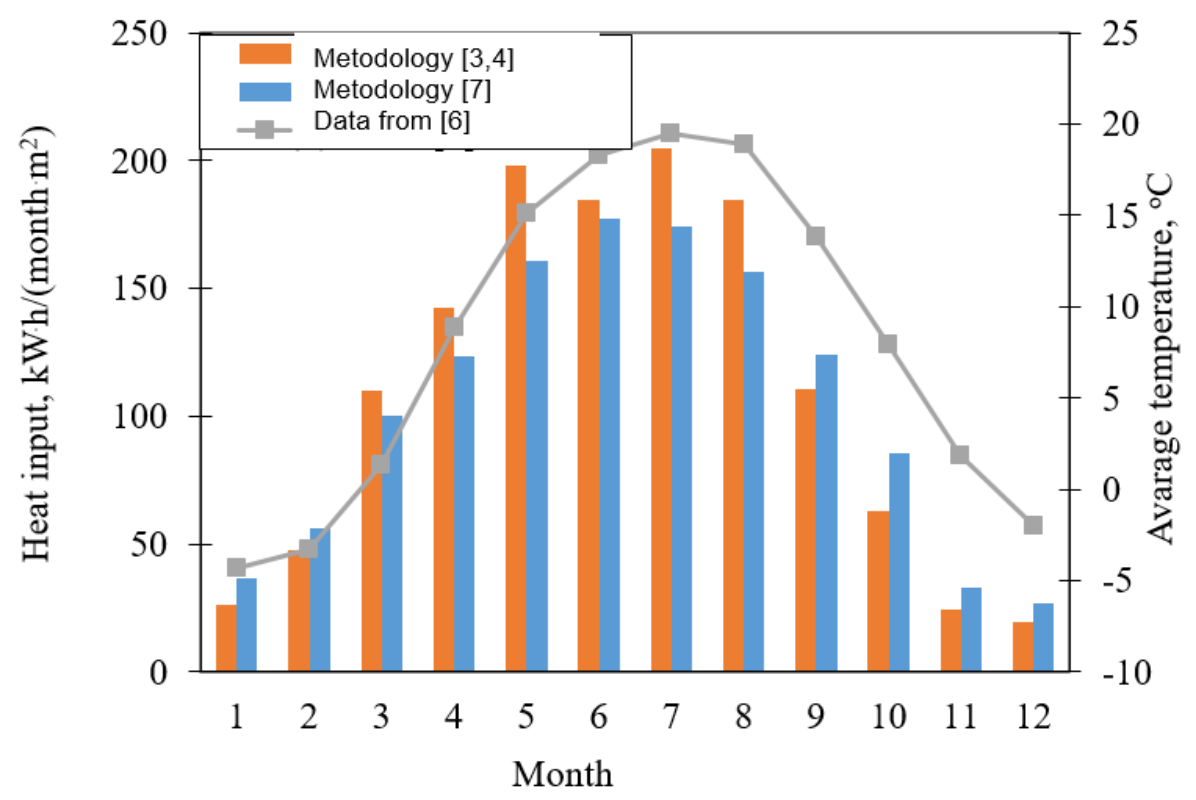

Fig. 4. Average monthly heat input from the solar collector to the heating system.

\section{THE DISCUSSION OF THE RESULTS}

In Fig. 5 shows the graphs of heat loss of the building in the cold period of the year and residual heat loss, taking into account compensation by their solar energy. The area under curve 1 is integrally equal to the heat loss of the building, and the area under curve 2 shows the residual losses during heating by the solar collector. It can be seen that in October and April full coverage of the heat load is possible due to insolation.

According to the results of calculations a single solar collector aperture of $2.3 \mathrm{~m}^{2}$ can be covered the heat loss of laboratory space area of $18 \mathrm{~m}^{2}$ at $35 \%$ in the cold season and receive $2142.7 \mathrm{~kW} \cdot \mathrm{h} /$ month in the warm season, which can be sent to a ground heat exchanger to compensate for the thermal state of the soil or to study the dynamics of heat transfer.

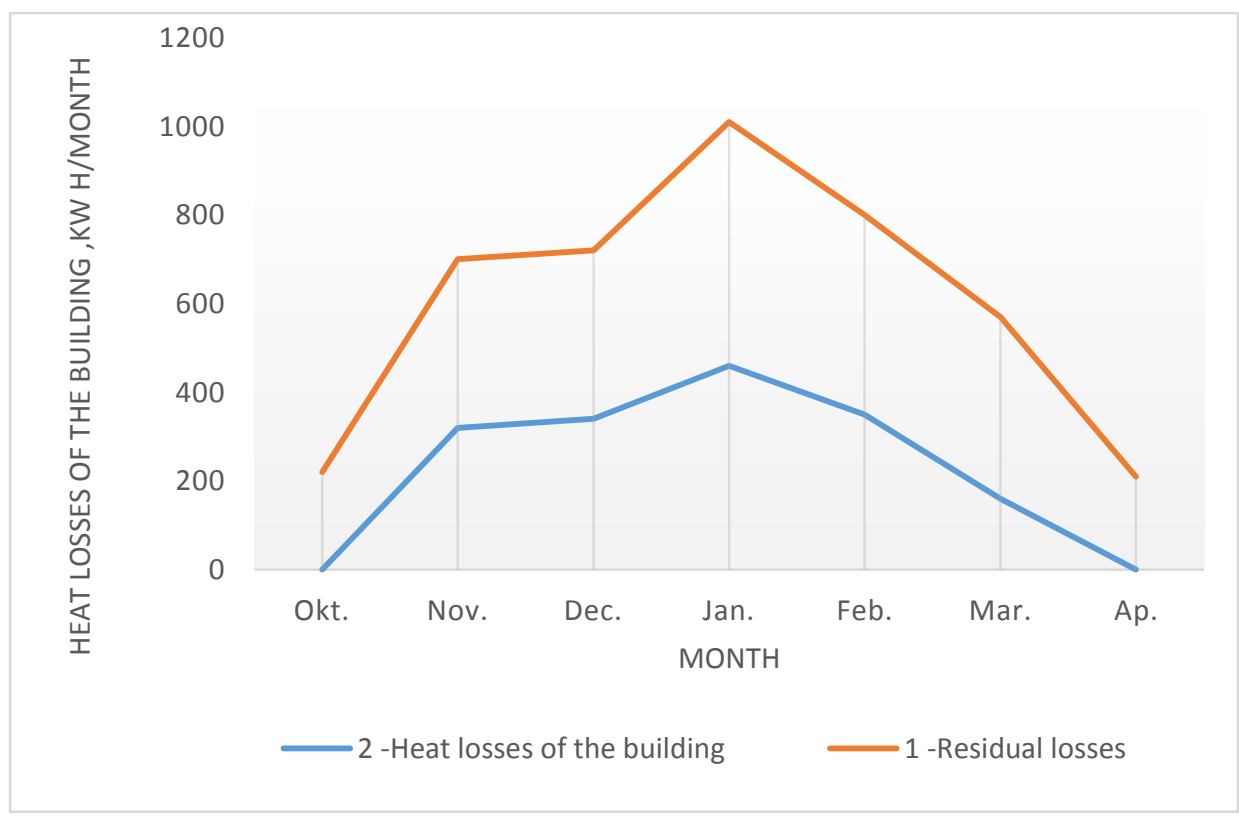

Fig. 5. Heat loss of the building. 


\section{ECONOMIC EVALUATION OF THE FEASIBILITY USING A COMBINED SOLAR ASSISTED GROUND SOURCE HEAT PUMP FOR SPACE HEATING}

For the analysis, a heat supply system of a conventional building with a total area of 200 $\mathrm{m}^{2}$ (with specific heat losses up to $40 \mathrm{~kW} \cdot \mathrm{h} /$ $\left(\mathrm{m}^{2}\right.$ year $)$ ) was applied flat solar collectors manufactured by Afros (Simferopol). The aperture area of one collector is $2 \mathrm{~m}^{2}$. The heat output of the heat pump manufactured by VDE - Ukraine (Brovary) is about $6 \mathrm{~kW}$. The paper considered two options for heating: with hot water and without it.

The results of the preliminary estimated calculations of the main thermal indicators carried out according to the methods of [13, 14, 15] are presented in Table 1. At the same time, the average monthly temperatures for the city of Kiev [17] were taken: January $=-4.3^{\circ}$ $\mathrm{C}$, February $=-3.3^{\circ} \mathrm{C}$, March $=1.3^{\circ} \mathrm{C}$, April $=8.9^{\circ} \mathrm{C}$, May $=15,1^{\circ} \mathrm{C}$, June $=18.3^{\circ} \mathrm{C}$, July $=19.5^{\circ} \mathrm{C}$, August $=18.9^{\circ} \mathrm{C}$, September $=$ $13.8^{\circ} \mathrm{C}$, October $=7.9^{\circ} \mathrm{C}$, November $=1,8{ }^{\circ} \mathrm{C}$, December $=-2.0^{\circ} \mathrm{C}$.

In the first variant, the heating system without domestic hot water supply (DHW) was considered. The required collector area was $26 \mathrm{~m}^{2}[14,15]$. The table shows the following values:

$Q_{h l}$ - heat loss from the building with a total area of $200 \mathrm{~m}^{2}$ for each calendar months. Since the heating period lasts from April 15 to October 15, during the period from May to September inclusive, the heat loss of the building is assumed to be zero.

$Q_{s k}$ - the average monthly heat input from the solar collector of the heating system.

$\Delta Q$ - the difference between the total heat loss of the building $Q_{h l}$ and monthly heat input from the solar collector $Q_{s k}$. Magnitude $\Delta Q$ with a positive sign, it shows how much heat energy it is possible to accumulate for further extraction, and $\Delta Q$ with a negative sign - how much heat loss needs to be covered with a heat pump and stored heat.

Thus, the sum of losses that are not covered by the collector is $20,441.9 \mathrm{~kW} \cdot \mathrm{h} /$ month, and the sum of the average monthly heat input from the solar collector to the heating system from April to October, taking into account the accumulation factor, which is assumed to be 0.8 , is $20,443.89 \mathrm{~kW}^{\cdot} \mathrm{h} /$ month. As a result of the calculations, we conclude that 13 collectors are sufficient to fully cover the heat losses of the building of $200 \mathrm{~m}^{2}$ during the heating period.

Table 1. The results of the calculation of the main thermal indicators of the system without hot water option

\begin{tabular}{|l|l|l|l|}
\hline Month & $Q_{h l}, \frac{k W \cdot \text { hour }}{\text { month }}$ & $Q_{s k}, \frac{k W \cdot \text { hour }}{\text { month }}$ & $\Delta Q, \frac{k W \cdot \text { hour }}{\text { month }}$ \\
\hline January & $6,175.20$ & 676.26 & $-5,498.94$ \\
\hline February & $5,349.12$ & $1,230.84$ & $-4,118.28$ \\
\hline March & $4,754.16$ & $2,860.52$ & $-1,893.64$ \\
\hline April & $1,364.40$ & $3,699.80$ & $\mathbf{2 , 3 3 5 . 4 0}$ \\
\hline May & 0 & $5,152.68$ & $\mathbf{5 , 1 5 2 . 6 8}$ \\
\hline June & 0 & $4,798.82$ & $\mathbf{4 , 7 9 8 . 8 2}$ \\
\hline July & 0 & $5,318.82$ & $\mathbf{5 , 3 1 8 . 8 2}$ \\
\hline August & 0 & $4,798.82$ & $\mathbf{4 , 7 9 8 . 8 2}$ \\
\hline September & 0 & $2,868.08$ & $\mathbf{2 , 8 6 8 . 0 8}$ \\
\hline October & $1,490.40$ & $1,629.68$ & $\mathbf{1 3 9 . 2 8}$ \\
\hline November & $4,478.40$ & 640.38 & $-3,838.02$ \\
\hline December & $5,594.80$ & 501.80 & $-5,093.00$ \\
\hline
\end{tabular}


We calculate the total cost of equipment and the payback period of such a system. The total capital expenditures on equipment, taking into account the installation work is $C E=$ 329,205 UAH (in prices as of 01.02.2018).

The saving of fossil fuels $B$ with the combined use of solar collectors and heat pump is calculated as [19] and shown in the formula (1)

$$
\begin{gathered}
B=\frac{\left(\sum Q_{s k}\right) \cdot 3600}{Q_{g} \cdot \eta_{b}}=\frac{31683,17 \cdot 3600}{35000 \cdot 0,9}=3620,9 \mathrm{M}_{g}{ }^{3} / \text { heating period } \\
Q_{g}=35 \mathrm{MД}-\text { heat of combustion } 1 \mathrm{M}_{g}^{3}
\end{gathered}
$$
natural gas;

$\eta_{b}=0,9-$ the efficiency of the boiler (adopted).

Below (2) the payback period $\tau$ of capital costs for a solar assisted ground source heat pump system compared with a different gas prices for $1000 \mathrm{~m}^{3}$ of natural gas $\mathrm{P}_{\mathrm{g}}=7000$ UAH, $8000 \mathrm{UAH}, 9000 \mathrm{UAH}$ is calculated.

$$
\tau=\frac{C E}{B \cdot P_{g}}
$$

The calculated results are shown in Fig.1. Obviously, with an increasing of gas tariffs, the payback period of the system significantly decreases.

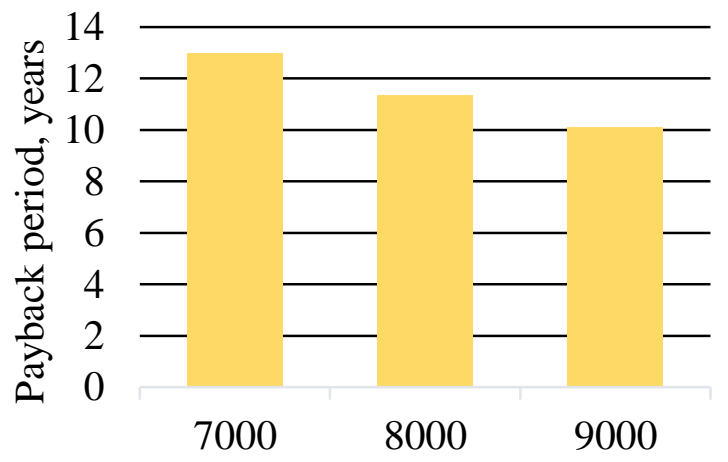

Price of $1000 \mathrm{~m} 3$ of natural gas, $\mathrm{UAH}$

Fig. 1. Dependence of the payback period of the system without hot water supply from gas tariffs.

In the second case, the heating system with consideration of hot water supply option was considered. Its main thermal indicators are given in table 2 . In the calculations it was assumed that 4 adults live in the cottage, and the consumption of hot water for each person is 100 liters per day. The required area of collectors in this case was $36 \mathrm{~m}^{2}[14,15]$.

Table 2. The results of the calculation of the system main thermal indicators with hot water supply option

\begin{tabular}{|l|c|c|c|c|}
\hline \multirow{2}{*}{ Month } & $Q_{h l}, \frac{k W \cdot \text { hour }}{\text { month }}$ & $Q_{s k}, \frac{k W \cdot \text { hour }}{\text { month }}$ & $Q_{D H W}, \frac{k W \cdot \text { hour }}{\text { month }}$ & \multirow{2}{*}{$\Delta Q, \frac{k W \cdot \text { hour }}{\text { month }}$} \\
\hline January & $6,175.20$ & 936.36 & 864.90 & $-4,373.94$ \\
\hline February & $5,349.12$ & $1,704.20$ & 781.20 & $-2,863.72$ \\
\hline March & $4,754.16$ & $3,960.72$ & 864.90 & -71.46 \\
\hline April & $1,364.40$ & $5,122.80$ & 837.00 & $\mathbf{2 , 9 2 1 . 4 0}$ \\
\hline May & 0 & $7,134.48$ & 864.90 & $\mathbf{6 , 2 6 9 . 5 8}$ \\
\hline June & 0 & $6,644.52$ & 837.00 & $\mathbf{5 , 8 0 7 . 5 2}$ \\
\hline July & 0 & $7,364.52$ & 864.90 & $\mathbf{6 , 4 9 9 . 6 2}$ \\
\hline August & 0 & $6,652.08$ & 864.90 & $\mathbf{5 , 7 8 7 . 1 8}$ \\
\hline September & 0 & $3,971.16$ & 837.00 & $\mathbf{3 , 1 3 4 . 1 6}$ \\
\hline October & $1,490.40$ & $2,256.48$ & 864.90 & $\mathbf{9 8 . 8 2}$ \\
\hline November & $4,478.40$ & 886.68 & 837.00 & $-2,754.72$ \\
\hline December & $5,594.80$ & 694.80 & 864.90 & $-4,035.10$ \\
\hline
\end{tabular}


The table presents the following values different from the previous table:

$Q_{D H W}$ - the amount of heat on the DHW by months;

$\Delta Q$ - the difference between the total heat load $Q_{h l}+Q_{D H W}$ and monthly heat input from the solar collector $Q_{s k}$.

With this version of the system, the total capital expenditures will be $C E=383,688$ UAH (in prices as of 01.02.2018).

The economy of natural gas with the combined use of solar collectors and heat pump [19] is calculated by the formula (3) and is equal to

$B=\frac{\left(\sum Q_{s k}\right) \cdot 6000}{Q_{g} \cdot \eta_{b}}=\frac{47328 \cdot 6000}{35000 \cdot 0,9}=9014,8 \mathrm{~m}_{g}{ }^{3} /$ heating period

The Fig. 2 shows the dependence of the payback period of the solar assisted ground source heat pump system with a hot water supply at the same gas prices as in the first case. The calculation was also carried out according to the formula (1) [19].

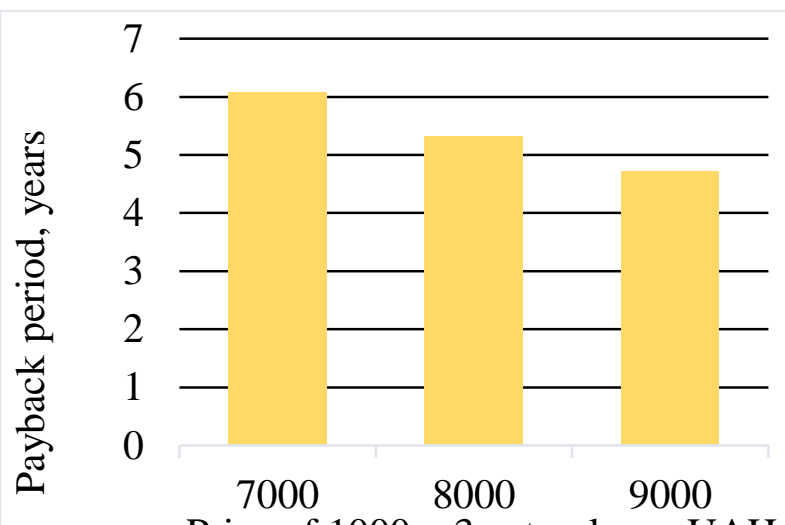

Price of $1000 \mathrm{~m} 3$ natural gas, UAH

Fig. 2. Dependence of the payback period of the system with hot water supply option from natural gas tariffs.

\section{RESULTS OF THE STUDY}

The research team has developed a hydraulic circuit diagram for a residential space heating system using a flat solar collector.
The scheme consists of three circuits (heating, solar collector and heat pump) passing through the storage tank, which allows them to hydraulically decouple from the implementation of heat exchange, as well as the contour of the vertical ground collector. In the cold period of the year, heat accumulates in the storage tank due to solar insolation and renewable heat of the ground with the heat pump assisting. By regulating the flow of heat carrier in the circuits and there switching maintained the required temperature in the storage tank and the heating circuit. Depending on the heating load, joint or single use of heat sources are possible. When the heat carrier reaches the temperature of the source returned from the solar collector, the circulating pump should be switched off automatically. Vertical double ground Ushaped heat exchanger is made of polypropylene pipes $\varnothing 32 \times 3.2 \mathrm{~mm}$, located in a well with a depth of $30 \mathrm{~m}$ [20].

While maintaining the trend of increasing prices for organic fuel, the transition to combined heat supply systems using alternative sources of heat seems to have no alternative. The results of the calculations show that using of hot water option of the heating system for a typical cottage with applying solar collectors and heat pump reduces the payback period of capital costs in general.

\section{REFERENCES}

1. Mysak Y., (2014). Solar energy: theory and practice: monography. Lviv Politechnic Publishing House, 340

2. Marek A., Karpinskia M., Pohrebennyk V., Kantora T., Mitryasovac O., (2004). Prospects of solar energy use in Ukraine Agricultural Engineering, 4 (152 ), 165 -173

3. Key Word Energy Statistics from the IEA, 2017 / OECD (IEA), 2017 URL: https://www.iea.org/publications/freepublicatio ns/publication/KeyWorld2017.pdf (application date: 04.03.2019)

4. Renewables 2018 / IEA, 2017 URL: https://www.iea.org/renewables2017/ (application date: 07.06.2019) 
5. Global solar atlas, 2019 URL: https://globalsolaratlas.info/ (application date: 06.03.2019)

6. Remap 2030 Background paper renewable energy prospects for Ukraine/IRENA, 2015 URL: https://www.irena.org//media/Files/IRENA/Agency/Publication/2015/ Apr/IRENA_REmap_Ukraine_paper_2015.pdf (application date: 07.06.2019)

7. Kjellsson, E., Hellstrom, G., Perrers, B. (2009). Optimization of systems with the combination of ground-source heat pump and solar collectors in dwellings. Energy, 35 (6), 2667-2673.

8. Helpin V., Kumert M., Cauret O. (2011). Experimental and simulation study of hybrid ground-source heat pump systems with unglazed solar collectors for French office buildings 12th conference of IBPSA proceedings. Sidney. Australia, 2957-2964

9. Inalli M, Esen H. (2004). Experimental thermal performance evaluation of 2 horizontal ground-source heat pump system. Thermal Engeering 24(14-15), 2219-32.

10.Huang B.J., Lee C.P. (2003). Long-term performance of solar-assisted heat pump water heater. Renewable Energy 29, 633-639

11.Ozgener O., Hepbasli A. (2005). Experimental investigation of the performance of a solarassisted ground- source heat pump system for greenhouse heating. Energy Research 29, $217-$ 231

12.Rad M.F. Fung A.S., Leong W.H. (2013). Feasibility of combined solar thermal and ground source heat pump systems in cold climate. Energy and Buildings, 61, 224-232.

13.Sparber W. Vajen K. Herkel S. (2011). Overview on solar thermal plus heat pump systems and review of monitoring results. International Energy Agency SHC program, 112.

14.Puhovoy I. (1992) Development and thermal calculations of solar heating systems. Kiev: Polytechnic, 1992, 24.

15.Chateauminois M., Mandineau D., Roux D., (2009). Tableau des temperatures du reseau froide Calcul d'installations solaire a eua, Collection de l'ESIM EDISUD

16.Bozhenko M.F., Salo V.P. (2004). Sources of heat supply and its consumers. Kiev: Polytechnic, 94.

17.Central Geophysical Observatory. Climate Cadastre of Ukraine, 2006. Nakorchevsky A.I. (2009). Calculation of the heat-receiving capacity of solar collectors // Industrial Heat Engineering, 31(2), $70-75$.

18.Zadoy A. (2009). Micro economy//Kyiv: Znannya, , 176.

20.Nedbailo A.N. (2010). Using a solar collector for space heating // Industrial Heat Engineering, $32(5), 66-70$.

\section{Аналіз застосування комбінованої системи сонячного нагрівання накопичувача наземного джерела теплового насоса для теплопостачання будівлі}

\section{Басок Б., Недбайло А., Тутова $О$. Ткаченко М., Божко I.}

Анотація. Представлені схемо технічні рішення і оціночні розрахунки основних параметрів системи теплопостачання адміністративного приміщення 3 використанням теплової енергії сонячного і грунтового колекторів. Схема складається 3 трьох контурів (опалення, сонячного колектора i теплового насоса), що проходять через бак-акумулятор, який дозволяє гідравлічно розв'язати їх із здійсненням теплообміну, а також контуру вертикального грунтового колектора. У холодний період року відбувається накопичення теплоти в баку-акумуляторі за рахунок використання теплоти інсоляції та відновлювальної теплоти грунтового масиву за допомогою теплового насоса.

За допомогою регулювання витрати теплоносіїв в контурах і комутацією останніх підтримується необхідна температура в баці-акумуляторі i для контурі опалення. Залежно від теплового навантаження опалення можливі варіанти спільного або одиночного використання джерел теплоти.

Розглянуто наступні технологічні варіанти роботи системи: циркуляція теплоносія через сонячний колектор i грунтовий теплообмінник, циркуляція теплоносія через сонячний колектор i тепловий насос, циркуляція теплоносія через грунтової теплообмінник і тепловий насос, циркуляція теплоносія через сонячний колектор до споживача. 
Розрахована частка покриття теплових втрат будівлі сонячним колектором для холодного періоду року.

Наведено оціночний технікоекономічний аналіз фінансових витрат при використанні комбінованої геліогрунтовой акумуляційної теплонасосної системи для теплопостачання приміщення. Для попередніх оцінних розрахунків основних фінансових показників розглянуті два варіанти системи теплопостачання будівлі: 3 урахуванням гарячого водопостачання в першому випадку і без нього.

Проведено порівняння енергоефективності комбінованої системи теплопостачання 3 традиційною системою при різних тарифах на природний газ.

Ключові слова: грунтовий колектор; тепловий насос; сонячний колектор; теплопостачання. 